THE EFFECTIVENESS OF APPLICATION OF THE DARSONVALIZATION FOR IMPROVEMENT OF A

\title{
CONDITION OF
}

PROSTHETIC BED MUCOSA AT THE PATIENTS USING
REMOVABLE DENTURES

Ziyadullaeva Nigora orcid.org/0000-0002-3786-8669

nigorazstom@yandex.ru

Tashkent state dental institute

Abstract

We suggest applying a darsonvalization method to improvement of a condition of a mucous membrane of a prosthetic bed. We have investigated 38 patients using complete removable dentures. After the carried-out 
darsonval-therapy for correction of haemodynamic of a prosthetic bed the level and intensity of a bloodstream have increased that has caused restoration of efficiency of the microcirculation. The long-term examination of patients after the darsonval-therapy has shown that it is necessary to correct the microcirculation of prosthetic bed tissues by method D'Arsonval each 6 months.

Key words: microcirculation, prosthetic bed, D'Arsonvalization, LDF, removable prosthetics, complete removable plate prostheses.

\section{ЭФФЕКТИВНОСТЬ ПРИМЕНЕНИЯ ДАРСОНВАЛИЗАЦИИ ДЛЯ УЛУЧШЕНИЯ СОСТОЯНИЯ СЛИЗИСТОЙ ОБОЛОЧКИ ПРОТЕЗНОГО ЛОЖА У ПАЦИЕНТОВ, ПОЛЬЗУЮЩИХСЯ СЪЁМНЫМИ ПЛАСТИНОЧНЫМИ ПРОТЕЗАМИ}

\section{Зиядуллаева Нигора \\ Ташкентский государственный стоматологический институт}

Мы предлагаем метод дарсонвализации для улучшения состояния слизистой оболочки протезного ложа. Мы обследовали 38 пациентов, пользующихся полными съёмными пластиночными протезами. После проведенной дарсонваль-терапии для улучшения гемодинамики тканей протезного ложа уровень и интенсивность микроциркуляции увеличилась, что, в свою очередь, улучшило эффективность микроциркуляции. Отдалённые результаты обследования пациентов после дарсонвализации 
показали, что коррекцию микроциркуляции протезного ложа методом Д'Арсонваль следует проводить каждые 6 месяцев.

Ключевые слова: микроциркуляция, протезное ложе, Д'Арсонвализация, ЛДФ, съёмное протезирование, полные съёмные пластиночные протезы.

Многие аппаратные процедуры в лечебной медицине основаны на воздействии на кожу человека электрическим током. Одной из таких процедур является дарсонвализация. Дарсонвализация - это физиотерапевтический метод, основанный на воздействии импульсного тока высокого напряжения, высокой частоты и малой силы.

Аппарат для дарсонвализации был изобретен 120 лет назад. Его созданию предшествовал ряд экспериментов с переменным током, которые проводил французский врач-физиолог Жак Арсен Д' Арсонваль. Он доказал, что воздействие импульсного тока благотворно влияет на состояние здоровья человека. Метод дарсонвализации оказался настолько действенным и недорогим, что быстро распространился по разным странам. Дарсонвализацию включили в схему лечения большинства болезней, а в последние десятилетия она широко применяется в косметологии.

Цель исследования. Доказать эффективность применения дарсонвализации для улучшения состояния слизистой оболочки протезного ложа у пациентов, пользующихся съёмными пластиночными протезами.

Показания к применению дарсонвализации: 
- Заболевания периферической нервной системы (невралгии, гипо- и парастезии, остеохондроз позвоночника, радикулит)

- $\quad$ Расстройства центральной нервной системы (неврозы, бессонница, мигрень, нейроциркуляторная дистония, энурез, нейродермит)

- Патологии кожи (угревая сыпь, экссудативный диатез, зудящие дерматозы, воспалительные инфильтраты, гиперфункция сальных желез)

- $\quad$ Целлюлит

- Нарушения кровообращения (трофические язвы, варикозное расширение вен, грибковое и бактериальное поражение кожи)

- Заболевания ЛОР-органов (нейросенсорная тугоухость, вазомоторный ринит, хронический гайморит)

- $\quad$ Воспаления слизистой оболочки полости рта

- Заболевания половых органов (простатит, импотенция, воспалительные процессы женских половых органов, сухость влагалища)

Противопоказания к применению дарсонвализации:

- наличие доброкачественных и злокачественных образований и опухолей,

- наличие кардиостимулятора,

- беременность,

- туберкулёз,

- эпилепсия,

- острые психические расстройства,

- лихорадочные состояния,

\section{Health Sciences}


электрического тока.

Механизм лечебного действия дарсонвализации. При контактной методике электрод скользит непосредственно по поверхности кожи или слизистой оболочки. Токи раздражают чувствительные нервные волокна, расположенные в толще кожи или слизистой, что активирует циркуляцию крови. Происходит кратковременный спазм сосудов, который сменяется длительным расширением за счёт прогревания тканей. В результате устраняются застойные явления, снимаются отёки. Лейкоциты интенсивно поглощают патогенные микроорганизмы (фагоцитоз), что приводит к скорейшему устранению воспалений. При бесконтактной дарсонвализации под действием разрядов электрического тока кислород из воздуха преобразуется в озон, который хорошо воспринимается кожей. Улучшается питание клеток и клеточное дыхание, активируются местная иммунная система.

При бесконтактной методике расстояние между электродом и поверхностью кожи составляет 210 миллиметров.

Общая дарсонвализация (индуктотерапия) - воздействие высокочастотным переменным током на все тело. Для этой процедуры используется аппарат - «клетка Д'Арсонваля». В последнее время общая дарсонвализация применяется редко.

Процедура дарсонвализации совершенно безболезненная. При проведении сеанса пациент может ощущать легкое приятное тепло или незначительное покалывание.

\section{Health Sciences}


Материалы и методы исследования. Основу аппарата для дарсонвализации составляют:

1 высокочастотный генератор, который формирует электрические импульсы,

2 повышающий трансформатор, питающий высоким напряжением электроды, 3 насадки, представляющие собой электрод для передачи импульсов пациенту. Электрод заключен в герметичную стеклянную колбу, заполненную разреженным воздухом. В комплект аппарата входит несколько насадок.

Нами было исследованно 38 пациентов, пользующихся частичными и полными съёмными пластиночными протезами. Процедуры проводились в положении больного сидя. Электроды дезинфицировали спиртом и смазывали вазелином для лучшего движения электрода. Воздействие проводили лабильным путем, при котором электрод свободно перемещался по слизистой протезного ложа. Напряжение на выходе электрода составляло 230 В на частоте 50 Гц. Во время процедуры пациент испытывал слабое тепло, иногда - ощущение пощипывания.

Процедуры проводили через день. Курс состоял из 6 процедур. 


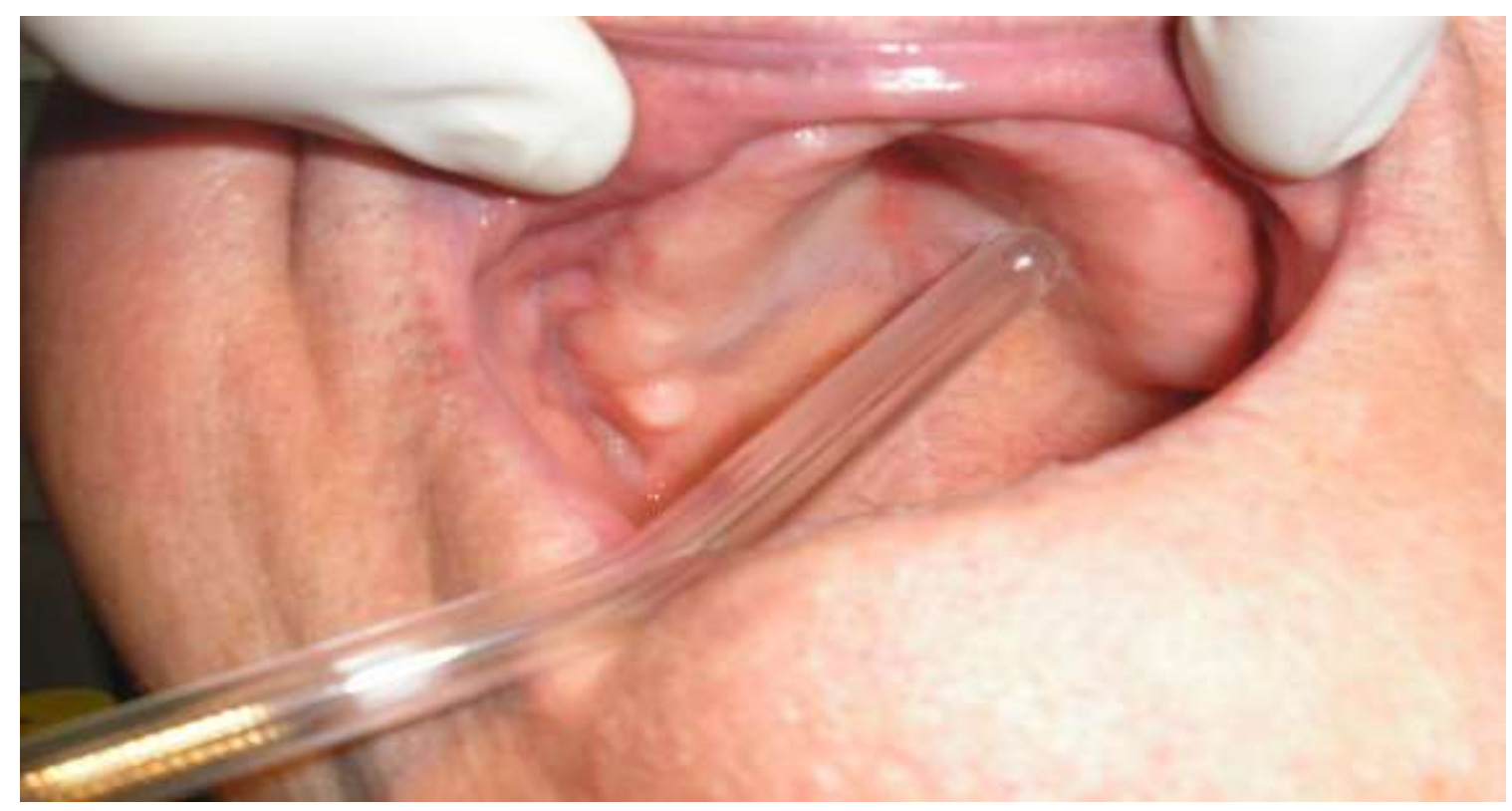

Результаты

исследования.

Клиникостоматоскопическое исследование пациентов этой группы выявило улучшение цвета слизистой оболочки протезного ложа уже на 6-7-й день лечения. Субъективные жалобы пациентов, чувствовавших дискомфорт при ношении протезов, выявил, что уже на 5-6 день лечения все неприятные ощущения в виде жжения и фантомных болей значительно уменьшались или проходили вообще. При объективном обследовании пациентов отмечалось улучшение состояния слизистой протезного ложа, которое характеризовалось ее уплотнением, улучшением цвета, выделением сосудистого рисунка. Улучшалась фиксация протеза на протезном ложе. На 11-12-й же день лечения цвет слизистой протезного ложа приобретал естественный равномерный бледнорозовый цвет без синюшных, бледных и гиперемированных участков. 
Результаты ЛДФ-грамм на 7-й день лечения свидетельствовали о повышении уровня кровотока и его интенсивности соответственно, при этом вазомоторная активность микрососудов уменьшалась. Анализ динамики амплитудно-частотных характеристик тканевого кровотока, проведенный на 11-12-й день лечения, обнаружил увеличение уровня вазомоций и высокочастотных флаксмоций, что свидетельствовало об усилении кровотока в артериальном и венулярном звеньях микроциркуляторного русла. Снижение уровня пульсовых флаксмоций свидетельствовало об улучшении венозного оттока в микроциркуляторном русле протезного ложа.

При повторном обследовании пациентов через 6 месяцев после проведенной дарсонваль-терапии результаты ЛДФ-грамм показали, что уровень микроциркуляции понизился, по сравнению с результатами последнего дня лечения, однако он был выше исходного значения на $4 \%$. Интенсивность капиллярного кровотока была снижена даже по сравнению с исходным значением, в ответ на что повышалась вазомоторная активность сосудов. Анализ АЧС ЛДФ-грамм показал, что уровни амплитуд всех волн приближались к исходным значениям.

Выводы. Таким образом, после проведенной дарсонваль-терапии с целью коррекции гемодинамики протезного ложа уровень и интенсивность кровотока увеличились, что повлекло за собой восстановление эффективности микроциркуляции.

Обследование больных, проведенное в отдаленные сроки после терапии, показало, что

\section{Health Sciences}


коррекцию микроциркуляции тканей протезного ложа методом Д'Арсонваль следует проводить каждые 6 месяцев. 


\section{References /Список литературы:}

1. Абаджян В. Н., Петрикос И. В. Влияние полных съемных протезов на слизистую оболочку протезного ложа // Материалы IX международной конференции челюстно-лицевых хирургов и стоматологов «Новые технологии в стоматологии». СПб, 2004. - С. 25-27.

2. Зиядуллаева Н. С. Гемодинамические показатели протезного ложа беззубой верхней челюсти и пути их коррекции: Дисс....к-та мед. наук. - Ташкент, 2007. - 105 c.

3. Шувалова Л. Я. Дарсонвализация в ранней реабилитации больных после дентальной имплантации: Дис. ... канд. мед. наук. - Москва, 2003. 109 c.

4. Хорев О. Ю., Майборода Ю. Н., Лола Д. В. Адаптация больных к съёмным пластиночным протезам // Сборник научных работ «Актуальные вопросы клинической стоматологии». - Москва, 2016. C. $2016-2018$

5. Bilhan H., Erdogan O., Celik M., Ates G., Geckili O. Complication rtes andpatient satisfactionwith removable dentures. J. Adv Prosthodont 2012, 4 - P. 109115

6. www.med.by Вакуум-дарсонвализация в лечении заболеваний пародонта и слизистой оболочки полости рта (Л. Н. Дедова)

7. http://medside.ru/apparat-darsonval

8. http://fizterapia.ru/mehanizm-vozdeystviyadarsonvalizatsii-na-organizm/ 